\title{
May There Be Peace: Teaching- Learning Approaches and Strategies in the Cultivation of Lasallian Peace Culture
}

\author{
Analiza D. Resurreccion ${ }^{1}$ \\ ${ }^{1}$ Department of Communication, College of Education, Arts, and Sciences, De La Salle Lipa, Lipa City, \\ Philippines \\ Correspondence: Ms. Analiza D. Resurreccion, Department of Communication, College of Education, Arts, and \\ Sciences, De La Salle Lipa, Lipa City, Batangas 4217, Philippines.
}

Received: August 22, 2016

Accepted: October 19, $2016 \quad$ Online Published: November 15, 2016

doi:10.20849/ajsss.v2i1.83

URL: http://dx.doi.org/10.20849/ajsss.v2i1.83

\begin{abstract}
This study sought to identify teaching- learning approaches and strategies in the cultivation of peace culture in De La Salle Lipa, Philippines. Interviews were conducted among selected professors in the College of Education, Arts, and Sciences who carry out peace initiatives through courses they teach. Content analysis of the syllabi of the courses that carry out peace concepts was also done. The findings identified holistic, participatory, cooperative, humanist, and experiential approaches evident in teaching courses that carry out peace concepts. It was recommended that the institution formalizes peace efforts if it is really committed to creating a condition conducive to peace whether at an intrapersonal, interpersonal, intergroup, national, or international level.
\end{abstract}

Keywords: peace education, peace concepts, culture of peace, transformative learning, peaceable teachinglearning process

\section{Introduction}

An education that promotes a culture of peace is essentially transformative (Castro \& Galace, 2010.) It focuses on the knowledge base, skills, attitudes and values that influence the mindsets, attitudes and behaviors of people that may in turn contribute to violent conflicts. This condition may be attained through building awareness and understanding, developing concern and challenging personal and social action. This will enable people to live, relate and create conditions and systems that actualize nonviolence, justice, environmental care and other peace values.

Peace education brings about behavior changes that enable children, youth, and adults to prevent conflict and violence, to create conditions conducive to peace at different levels, and to resolve conflict peacefully. In this process, the knowledge, skills, attitudes, and values needed are primarily promoted (UNESCO, 2002).

An education that is "directed to the full development of the human personality and to the strengthening of respect for human rights and fundamental freedoms, promoting understanding, tolerance and friendship among all nations was called in UNESCO's early declaration on a culture of peace (UNESCO, 1945). It emphasizes peace education as a humanizing process of teaching and learning, which facilitates human development by counteracting the dehumanization of poverty, prejudice, discrimination, rape, violence, and war. By bringing in the concept of empowerment, Harris (1988) adds to this "humanizing" approach for he believes that peace education is the process of empowerment. This kind of empowerment is expected to enable underprivileged groups to learn, feel, and use their power and influence; thus, students and community members are engaged to resolve their own problems and conflicts. Harris identifies different stages for empowerment. These include 1. overcoming feelings of powerlessness; 2. confronting deep-seated fears of violence; 3 . increasing awareness of public affairs; 4 . leadership training; and 5. taking action. The primary concern of peace education anyway is the reconciliation of society, protection of human rights, and development of peace skills (Salomon, 2002).

Peace education that is fundamentally dynamic, interdisciplinary, and multicultural brings together multiple traditions of pedagogy, theories of education, and international initiatives for the advancement of human development through learning. It grows out therefore of the work of educators. Peace education not only builds principles and practices that have evolved over time, but also responds to different historical circumstances. It 
aims to cultivate the knowledge, skills, and attitudes needed to achieve and sustain a global culture of peace. It centers on understanding and transforming violence.

Peace education as a practice in schools is attributed to Maria Montessori, John Dewey and Paulo Freire, though earlier thought on education for peace is tracked back to Erasmus and Socrates, among other scholars. It is a problem- posing education that builds the universal values and behaviors in every person on which a culture of peace is predicated. It includes the development of non- violent conflict resolution skills and a commitment to working together to realize a shared and preferred future.

On February 19, 2010 De La Salle Lipa launched the Regional Center for Peace Education. The then President Br Mannuel Pajarillo, FSC noted " if we have institutionalized military trainings in schools for so long, why not institutionalize peace education?"

In the pursuit of embracing a culture of peace in the Lasallian learning environment, this study aims at identifying teaching- learning approaches and strategies in the cultivation of peace culture in De La Salle Lipa, Philippines.

\subsection{Review of Related Literature}

Peace education is teaching for and about human rights, gender equality, disarmament, social and economic justice, non- violence, sustainable development, international law, and traditional peace practices. In the realization of peace education, critical thinking, reflection and participation must be embraced. These, too, should be integrated into the pedagogy of all teaching at all levels of education.

Peace education must first develop an awareness and understanding among the youth as well as adults on the ramifications and roots of particular conflict. They must also know possible alternatives in overcoming such. Then through reflection, discussion and use of perspective- taking technique they will be asked to look at the various perspectives. They will try to put themselves on the shoes of others and cultivate empathy for the victims of violence and for those whose perspective may also have legitimacy but whose perspective is different from ours.

The learning process that is utilized in peace education, therefore, is holistic. It tries to address the cognitive, affective and active dimensions of the learner. Normally, the process includes introduction of relevant new knowledge or reinforced knowledge, posing valuing questions and using discussion and other participatory methods to cultivate concern, and eliciting/challenging/encouraging appropriate personal and social action.

Transformation attempts may include that, that is against prejudice and the war system, or that, that is for social and economic justice. Paying attention to cognitive, affective and active levels increases the possibility that the peace perspective or value that is being cultivated would be internalized. The following figure illustrated this process in graphic form. 


\section{THE PEACEABLE TEACHING-LEARNING PROCESS}

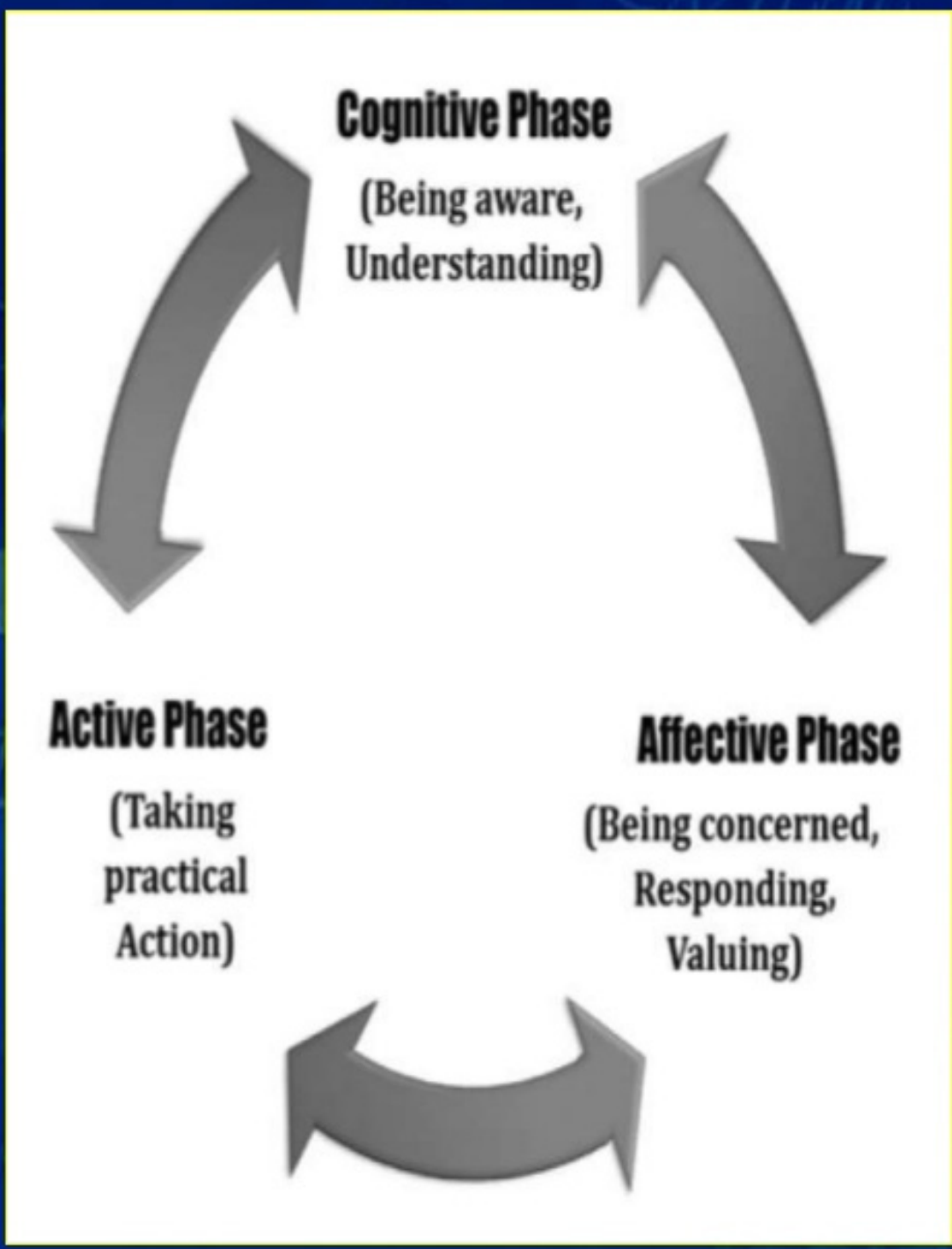

Source: http://www.slideshare.net/EST_062394/peace-education-39742523

Why educate for peace?

Peace education seeks to transform the present human condition by "changing social structures and patterns of thought that have created it" as stated by Betty Reardon, in her book, Comprehensive Peace Education: Educating for Global Responsibility (1988). She reminds us that peace education has an important social purpose. She carries this perspective forward in her book Learning to Abolish War; Teaching toward a Culture of Peace 
(Reardon \& Cabezudo, 2002 cited in Castro \& Galace, 2010). It is also noted in this book that the main purposes of peace education are the elimination of social injustice, the rejection of violence and the abolition of war.

\section{Schema of knowledge, skills and attitudes/values}

Based on a survey of peace education literature and of key informants/ peace educators that was done by the Center for Peace Education of Miriam College, a list of key knowledge areas, skills, attitudes and values that are integral to peace education have been identified. This, though, is not exhaustive and is expected to evolve, as peace education practice and experiences as well as corresponding reflections and insights on these experiences increase.

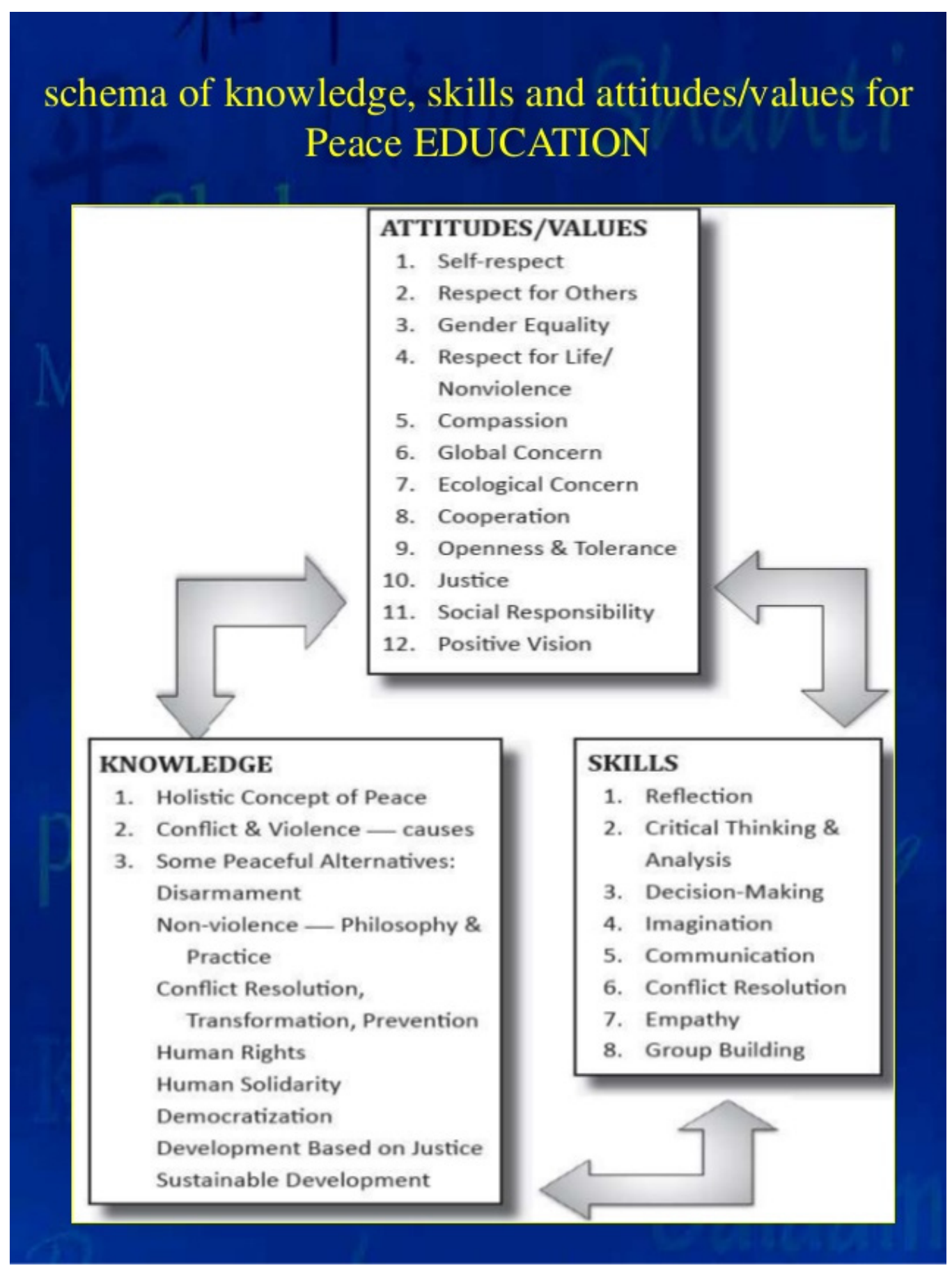

Source: http://www.slideshare.net/EST_062394/peace-education-39742523 


\section{Teaching- learning approaches and strategies in peace education}

Education that is holistic, participatory, cooperative, experiential and humanist are identified compatible with the goals of peace education.

Holistic education promotes cognitive, affective and behavioral goals of learning. Transmission of concepts is often the focus of learning. The goals are three- fold in peace education: 1. building of awareness on the roots of peace; 2. building of concern and the development of the values of empathy, comparison, hope and social responsibility; and, 3. call to action beginning with the resolve to change personal mindsets and attitudes and doing something concrete about situations of violence. Harris \& Morrison (2003) refer to the second as the development of moral sensitivity culminating in the building of the capacity of learners to care for others.

Participatory education allows learners to inquire, share and collaborate. It gives learners an opportunity to engage in dialogue with the teacher as well as with their co- learners. Broadening of perspectives practice is achieved through articulating and listening to diverse points of view. Teacher acts more of a facilitator in this kind of learning. Teachers encourage students to articulate their own perspectives then invite them to take appropriate action on the issues discussed (Mcginnis, 1984 cited in Castro \& Galace, 2010). Participatory education also means veering away from the traditional indoctrination style. The observance of democratic processes in the classrooms can contribute to the development of knowledge, skills and attitudes necessary for democratic citizenship (Harris \& Morrison, 2003 cited in Castro \& Galace, 2010).

Cooperative learning gives opportunities for participants to work together and learn, rather than compete with each other. Aside from increasing motivation to learn, this approach improves relations among students. It challenges individualism; and lessens divisiveness and feelings of prejudice. It reverses feelings of alienation and isolation, thus, promotes more positive attitudes. In a cooperative classroom, students learn to rely on each other. The success of learning activities depends upon the contributions of each one (Harris and Morrison, 2003).

In Experiential education learning is not through didactic means but through the processing of one's experience from activities initiated in the classroom. Learners build ideas. They, then form concepts drawn from the experience or activity they went through.

In a humanist classroom, social, personal and affective growth of the learners are emphasized. Individuals are accepted for what they are. Humanist education develops the notions of the self to promote a sense of selfesteem. It sends the messages that are valuable and gifted. Mcginnis (1984) says that "without a positive selfconcept or self- image, no one takes a stand, 'goes public', or works for change." He also posits that the more aware we are of our giftedness, the more willing we become to share our gifts with others. Teachers in a humanist classroom show interest and concern for the well- being of students. They are empathetic and affirming. Care and respect for each other are encouraged among learners. They emphasizes value of sensitivity to diversity in the classroom. This kind of education helps breed in learners the seeds of love and compassion which are necessary in building a peaceable society.

Teaching learning strategies that are compatible with the holistic, participatory, collaborative, experiential and humanist approaches to peace education identified by Castro \& Galace in their book Peace Education: A Pathway to a Culture of Peace include discussion, pair share, visualization or imagination exercise, perspectivetaking, role playing, and simulation games. Teachers may also consider problem solving, stating positions or issue poll, encouraging action, reading or writing a quotation, web- charting, use of films or photographs, telling stories, and song or poem analysis. Other strategies that are helpful are sentence completion, journal writing or journal completion, go- round, teachable moments, interviews, research, expert resources, reciprocal teaching, twinning, dialogues, exposure trips, use of globes and maps, brainstorming, reading quotations, use of charts and graphs, case studies, collage- making, and, show and tell.

The aforementioned approaches and strategies are important tools to develop students' intellect, attitudes and spirit for them to be inspired to work for peace.

\subsection{Significance}

De La Salle Lipa, being the Regional Center for Peace Education initiates activities that give opportunities to every student and every Lasallian partner to experience a culture of peace. Yet these initiatives may be strengthened if the institution's attempt to integrate peace concepts in some courses in the tertiary level will be formalized. Through this study, the institution would have a concrete basis on whether or not there is still a need to explicitly integrate concepts of peace in the curriculum of other courses. More so, it will be determined if the approaches as well as the strategies applied by the professors are already enough for the students to realize how important it is to develop an understanding of peace at different levels. 


\subsection{Statement of the Problem}

This descriptive research is a study on the teaching- learning approaches and strategies in the cultivation of Lasallian peace culture. The following questions constitute the problem of this study.

1. Are there academic- related initiatives that pursue peace education?

2. What are the courses that carry out peace concepts?

3. At what year levels peace concepts are being carried out?

4. What key peace education themes are being pursued?

5. What are the different strategies used in carrying out peace concepts?

6. Is there an explicit advocacy of peace concepts using visual media in terms of themes and content?

\subsection{Assumption}

Visual media is an excellent media for communicating both emotional and behavioral information; thus, have wider breadth in teaching peace concepts.

\subsection{Conceptual Framework}

This presents the diagrammatic representation of the objectives of this study.

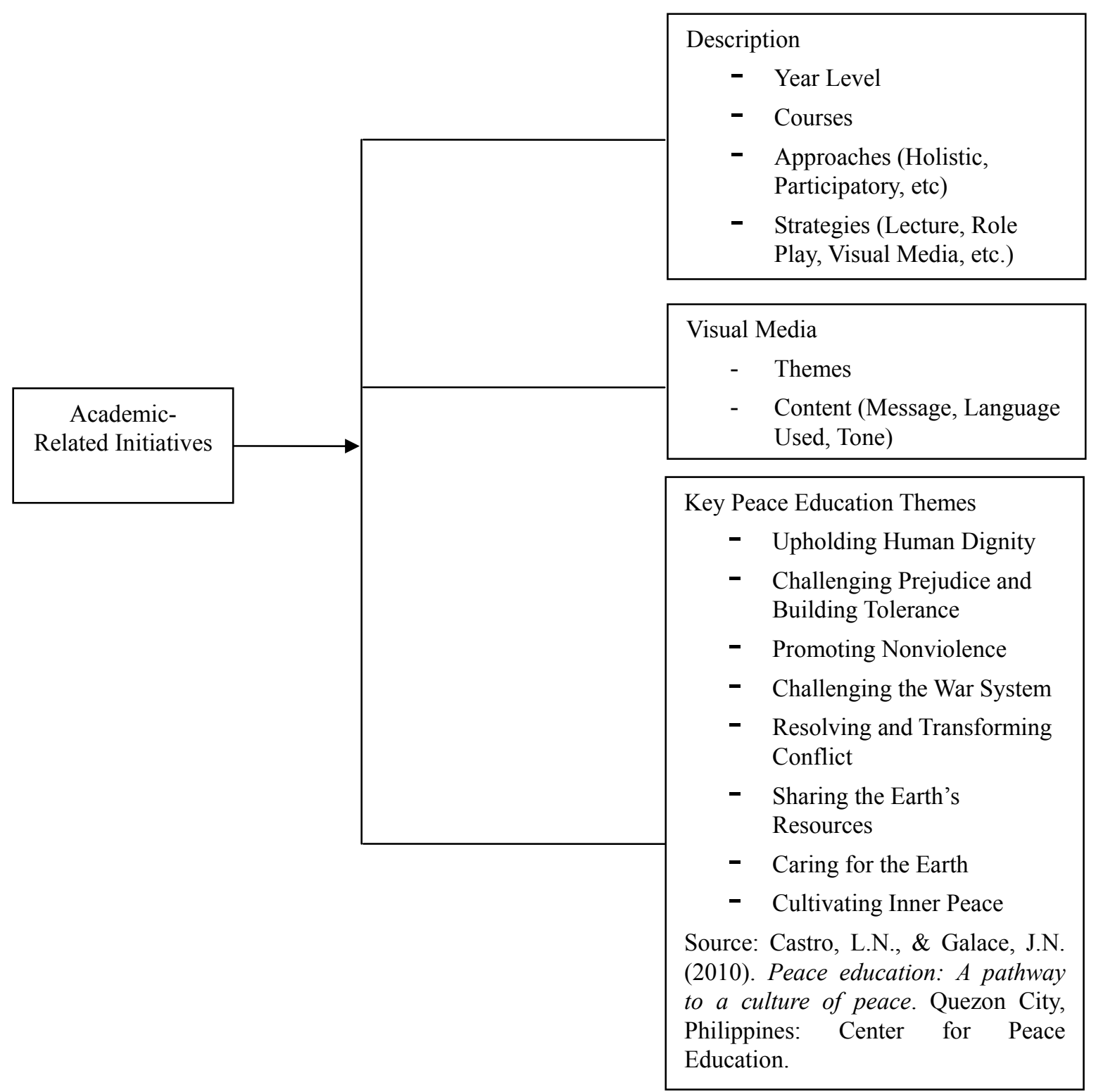


Teaching- learning strategies that are compatible with holistic, participatory, cooperative, experiential and humanist approaches in peace education as identified in the book of Castro \& Galace, 2010 include discussion, pair share, visualization/imagination exercise, perspective- taking, role- playing, simulation games, problemsolving, considering positions/issue poll, encouraging action, reading or writing a quotation, web- charting, use of film and photographs, telling stories including personal stories, song/ poem analysis, sentence completion, journal writing/individual reflection, go-round, teachable moments, interview/research, expert resources, reciprocal teaching, twinning, dialogues, exposure trips, use of globes and maps, brainstorming, reading quotations, use of charts and graphs, case studies, collage- making, and, show and tell.

Video is a powerful communication tool because of its ability to deliver basic knowledge and skills training, as well as to communicate and model behavioral information. Using video to model positive behavior, teach new skills or explain concepts can help accelerate the process of learning - for both teachers and students. It is also a versatile tool that can demonstrate complex techniques such as conflict resolution and motivate change by showing success stories. It is an excellent media for communicating affective (emotional or behavioral) information. [Available at] http://spectrummedia-boston.com/downloads/peace_teaching_project.pdf

Visual media have the ability to illustrate through pictures, it is especially valuable for communicating affective information. Video has long been used to enhance training programmes because of its capacity to communicate and model behavioral information. Video also excels in delivering basic knowledge and skills training. When it comes to teaching conflict resolution techniques that are often unfamiliar to teachers in many parts of the world, video makes it easier by allowing the viewer to see how it is done.

Video can be a powerful tool for peace education and non- violent conflict resolution skills training:

Videos can create a visual classroom for educators. Many teachers who want to bring conflict resolution skills to their students often have no trainings in this area; they are unclear as to what this type of teaching actually looks like in practice. Videos can illustrate how effective conflict resolution education techniques are practiced in schools and classrooms much like their own.

Videos can provide visual examples of activities, curriculum and programmes. The videos can also demonstrate that peace education activities can be done simply and with limited resources.

Videos can share cross- cultural ideas and can enrich students' learning experience. Seeing others participate in peace education activities can motivate students to model similar behavior. It can also show them cultures and communities they may otherwise never discover. [Available at] http://www.ineesite.org/uploads/files/resources/subdoc_1_676_Analytical_Review_of_Selected_Peace_Ed_Mat erials.pdf

\section{Key Peace Education Themes}

Castro \& Galace, 2010 in their book Peace Education: A Pathway to a Culture of Peace identified key peace education themes as follows: 1 . upholding human dignity; 2 . challenging prejudice and building tolerance; 3 . promoting nonviolence; 4 . challenging the war system; 5. sharing the earth's resources; 6 . caring for the earth; 7. cultivating inner peace; and, 8. resolving and transforming conflicts.

\section{Methods}

This descriptive study made use of key informant interviews and content analysis. Key informant interviews involve interviewing a select group of individuals who are likely to provide needed information, ideas, and insights on a particular subject. Interviewees were selected professors of Religious Studies, and National Service Training Program (NSTP). They were from the College of Education, Arts, and Sciences, De La Salle Lipa. Since departmental approach in teaching courses under the abovementioned areas is being observed, the researcher need not conduct interview with all the professors handling the courses that carry out peace concepts.

Content analysis is a research tool used to determine the presence of certain words or concepts within texts or sets of texts. Content analysis of the syllabi of the courses that carry out peace concepts - Cristology and Discipleship (RELED12), Church, Sacraments, and Family Life (RELED21), Christian Morality (RELED22), National Security Concerns and Peace Education (Module6), and Special Topic1: Peace Education - was also done. This intended to determine the approaches and strategies in teaching peace concepts identified by the professors teaching the abovementioned courses as well as the key peace education themes that are being carried out.

The researcher also conducted some literature reviews to determine other academic initiatives of the institution that carried out peace concepts after it was being launched as the Regional Center for Peace in February 2010. 


\section{Results and Discussion}

1). De La Salle Lipa being the Regional Center for Peace Education take steps in the realization of peace as a way of life in the region specifically inside campus. On September 22, 2014, the entire DLSL community celebrated Peace One Day with the theme "Creating a Culture of Peace: Living the Faith, Sharing the Dream, Living the Faith." The Peace One Day commenced with a Mass for Peace participated by select students, faculty and staff. It was highlighted by symbolic offering of white flower which symbolizes pure love and intention of achieving peace in Mother earth; globe symbolizes all nations in the world to be united and unified in promoting peace; white dove symbolizes the youths untiring desire to continue flying and dreaming of a peaceful place to live in; cross symbolizes that as the community continue its journey of life, may it also continue the journey in keeping everyone's heart flaming in peace; statue of St. La Salle symbolizes that with prayers and guidance from St. La Salle, may the community be an effective instrument in provoking desire to find peace in mankind. The institution also observed A Fast For Peace which kept the community from making unnecessary noises and abstained from the use of electronic gadgets to feel and experience a peace and quiet moment in school. Other activities include 1. a prayer brigade dubbed A Prayer Vigil For Peace, with special intention for world peace, during the students Christian Living, Social Studies and English classes; 2. Film Viewing regarding Peace One Day; and 3. Photography Contest themed "Fraternity, A Foundation and Pathway to Peace". [Available at] http://www.dlsl.edu.ph/24ff42e5b65bf52e5fb66291233ecf6bbbc9d72bf34aff5a4b22ecde9fa6c8d4news_redirect. asp?queryNews $=1824$

On September 30, 2013, Peace One Day Celebration aimed at promoting the value of togetherness and community in prayers for peace and unity and deepening faith in God as everyone experiences inner peace. Highlight of the said celebration were Planting of Peace Pole and Blessing of Peace Garden which was participated by selected students, and Prayer Vigil for Peace which was participated by students and faculty. This participation of De La Salle Lipa community in the global celebration of Peace One Day made it to the shortlist of the Largest Event category of the Face to Faith Peace One Day Awards 2013 which was participated by 102 schools from 13 countries, namely, Egypt, India, Indonesia, Italy, Jordan, Lebanon, Mexico, Pakistan, Philippines, UAE, UK, Ukraine, and USA. [Available at] http://www.dlsl.edu.ph/24ff42e5b65bf52e5fb66291233ecf6bbbc9d72bf34aff5a4b22ecde9fa6c8d4employeesann ouncements_redirect.asp?queryEmployeesAnnouncements $=1411$

Aside from the aforementioned initiatives, peace concepts integration in the curriculum is being sustained in the institution. In the College of Education, Arts, and Sciences, peace concepts are being carried out in teaching the following courses: Cristology and Discipleship (RELED12), Church, Sacraments, and Family Life (RELED21), Christian Morality (RELED22), National Security Concerns and Peace Education (Module6), and Special Topic1: Peace Education.

2). Peace concepts are being carried out in Christology and Discipleship (RELED12), Church, Sacraments, and Family Life (RELED21), Christian Morality (RELED22), National Security Concerns and Peace Education (Module6), and Special Topic1: Peace Education.

3). Second year college students, all programs, take Christian Morality (RELED22) and Church, Sacraments, and Family Life (RELED21). First year college students, all programs, take Christology and Discipleship (RELED12) and National Security Concerns and Peace Education (Module6). Third year Education students take Special Topic1: Peace Education.

4). In Christology and Discipleship (RELED12), peace education themes that are being carried out are 1. Challenging Prejudice and Building Tolerance, and 2. Promoting Nonviolence under the topic The World of Jesus. Same themes along with Upholding Human Dignity are being carried out under the topic Public Ministry.

In Church, Sacraments, and Family Life (RELED21) and Christian Morality (RELED22), peace education concepts that are being carried out are not explicitly identified in the syllabi.

In National Security Concerns and Peace Education (Module6), peace education themes that are being carried out are 1. Cultivating Inner Peace, 2. Caring for the Earth, 3. Challenging the War System, 4. Upholding Human Dignity, and 5. Resolving and Transforming Conflict.

In Special Topic1: Peace Education, all peace education themes are being carried out.

5). Lecture, Discussion, and Simulation are the strategies in teaching peace concepts in Christology and Discipleship (RELED12). Interviewee specified that peace concepts are emphasized in the topic Teachings of Christ. This is supported by the lesson objective identified in the syllabus, that is, to infer and reflect upon then 
wisdom that comes out of Jesus' radical teachings on forgiveness, compassion, healing, well- being, freedom, peace and love.

Lecture as well as Case Study and Research in groups are the strategies in teaching peace concepts in Christian Morality (RELED22) identified by the interviewee. Reiterations of peace concepts are made through students Creative Audio Visual Presentations about moral issues (advocacy campaigns). These, though, are not explicitly identified in the syllabus.

Lecture and Discussion are the strategies in teaching peace concepts in Church, Sacraments, and Family Life (RELED21). Neither in the interview nor in the syllabus, reiterations on teaching peace concepts were identified.

Lecture, Quiz Bee, Peace Photo Presentation, Debate, and Audio Visual Presentations are the strategies in teaching peace concepts in National Security Concerns and Peace Education (Module6). In the conduct of debate, processing of insights followed after students expressed views about issues concerning peace.

Lecture, Interactive Discussions, Film Viewing, Think- Pair - Share, Case Analysis are the strategies in teaching peace concepts in Special Topic1: Peace Education that are explicitly identified in the syllabus.

6). Neither in the interview nor in the syllabus, explicit advocacy of peace concepts were identified.

\section{Conclusions and Recommendations}

Based on the findings presented, the researcher come up with the following conclusions.

Academic initiatives in carrying out peace concepts are clearly observed in De La Salle Lipa. These are made through the celebration of Peace One Day in observance of the World Peace Day in the month of September. Integration of peace concepts in the curriculum is also made. Though, the use of visual media which is a powerful communication tool because of its ability to deliver basic knowledge and skills training, as well as to communicate and model behavioral information is not maximized.

Holistic approach is evident in teaching Christology and Discipleship (RELED12) and Church, Sacraments, and Family Life (RELED21). The strategies identified promote cognitive, affective and behavioral goals of learning. Participatory education on the other is evident in Christian Morality (RELED22) for the strategies used allow learners to inquire, share and collaborate as they conduct research and case study. Cooperative learning is also evident by allowing students to do Creative Audio Visual Presentations, giving them opportunities to work together and learn.

Holistic, Participatory, Cooperative, and Experiential learning approaches are evident in teaching peace concepts in National Security Concerns and Peace Education (Module6). The strategies identified do not just promote cognitive, affective and behavioral goals of learning, these also allow learners to inquire, share and collaborate. Moreover, students are also given opportunities to work together and learn as they do peace photo and audio visual presentations. Learning is not just through didactic means but through the processing of one's experience from activities like debate and quiz bee initiated in the classroom.

Aside from the aforementioned approaches, humanist learning is evident in teaching peace concepts in Special Topic1: Peace Education. The use of interactive discussions and think-pair-share strategies emphasizes the social, personal, and affective growth of the students.

Evidently, there is still a need to explicitly integrate concepts of peace in the curriculum of other courses. More so, other approaches as well as strategies must be applied by the professors for the students to realize how important it is to develop an understanding of peace at different levels.

In view of the findings, it is recommended that

1). De La Salle Lipa formalizes peace efforts if the institution is really committed to creating a condition conducive to peace whether at an intrapersonal, interpersonal, intergroup, national, or international level.

2). Integrate visual media as a complementary component of peace education. It can play a critical role in inciting violence, by transmitting biased information and exacerbating war or, in consolidating peace, by promoting tolerance, providing information with objectivity and bringing elements to understand social context. (The Power of Media, 2003)

3). Professors may use other teaching learning strategies that are compatible with the approaches to peace education (song/poem analysis, twinning, exposure trips, expert resources, collage- making) 


\section{References}

Bryman, A. (2004). Social research methods (2nd ed.). Oxford: Oxford University Press.

Castro, L.N., \& Galace, J.N. (2010). Peace education: A pathway to a culture of peace. Quezon City, Philippines: Center for Peace Education.

Education for peace: Content, form, and structure: Mobilizing youth for civic engagement. Retrieved from http://www.review.upeace.org/index.cfm?opcion=0\&ejemplar=19\&entrada=101

From face to faith. from http://www.dlsl.edu.ph/24ff42e5b65bf52e5fb66291233ecf6bbbc9d72bf34aff5a4b22ecde9fa6c8d4employee sannouncements_redirect.asp?queryEmployeesAnnouncements $=1411$

Harris, I., \& Morrison, M. (2003). Peace education. Jefferson, North Carolina: McFarland and Company, Inc.

Harris, I. (1988). Peace education. Jefferson, NC: McFarland.

Hay, C. (2002). Political analysis. Palgrave: Basingstoke.

Hirst, P., \& Thompson, G. (1999). Globalization in Question (2nd ed.). Polity press, Cambridge.

Inter- agency peace education programme: Analytical review of selected peace education materials. Retrieved from

http://www.ineesite.org/uploads/files/resources/subdoc_1_676_Analytical_Review_of_Selected_Peace_Ed _Materials.pdf

Learning the way of peace. Retrieved from http://unesdoc.unesco.org/images/0012/001252/125228eo.pdf

Lee, H. (1960). To kill a mockingbird. NY: Harper Collins Publishers.

Mayor, F. (2005). Democracy, nonviolence, and peace. In Peter Blaze Corcoran, Mirian Vilela, and Alide Roerink (Eds.), The Earth Charter for Action: Toward a Sustainable World (pp. 117-119). Amsterdam: KIT Publishers.

Mcginnis, J. (1984). Educating for peace and justice. MO: The Institute for Peace and Justice.

Peace one day 2014.2 Retrieved from http://www.dlsl.edu.ph/24ff42e5b65bf52e5fb66291233ecf6bbbc9d72bf34aff5a4b22ecde9fa6c8d4news_red irect.asp?queryNews $=1824$

$\begin{array}{lllll}\text { Peaceable teaching- } & \text { learning } & \text { process. }\end{array}$ http://www.slideshare.net/EST_062394/peace-education-39742523

Reardon, B., \& Cabezudo, A. (2002). Learning to abolish war: Teaching toward a culture of peace. New York: Hague Appeal for Peace.

Reardon, B. (1988). Comprehensive peace education. New York: Teachers College, Columbia University.

Salomon, G. (2002). The nature of peace education: Not all programs are created equal. In G. Salomon and B. Nevo (Eds.), Peace education: The concept, principles and practices around the world (pp. 3-14). Mahwah, NJ: Lawrence Erlbaum Associates, Inc.

Schema of knowledge, skills, and attitudes/values for peace education. Retrieved from http://www.slideshare.net/EST_062394/peace-education-39742523

Sri Lankan teachers as agents of peace. Retrieved from http://educationanddevelopment.files.wordpress.com/2008/04/master-these-ids-sri-lankan-teachers-as-agent s-of-peace-cc3a9line-hoeks.pdf

Strategies for integrating peace education into Social Studies curriculum for junior secondary (Basic 7-9) schools in Nigeria. Retrieved from http://afrrevjo.net/journals/multidiscipline/Vol_6_no_3_art_16_Ezeoba.pdf

Teacher as learner: Theory and pedagogy. Retrieved from http://www.un.org/cyberschoolbus/peace/frame.htm

The concept and perception of peace education in Gilgit Baltistan Pakistan: A Comparative Case Study. Retrieved from http://www.review.upeace.org/index.cfm?opcion=0\&ejemplar=24\&entrada=127

The peace teaching project: Resources for conflict resolution. Retrieved from http://spectrummedia-boston.com/downloads/peace_teaching_project.pdf

The power of the media: a handbook for peace builders. (2003). Edited by Ross Howard, Francis Rolt, Hans van de Veen and Juliette Verhoeven. Amsterdam: European Center for Conflict Prevention. 
UNESCO. (1945). Culture of peace: A declaration on a culture of peace. Retrieved from www.unesco.org/cpp/uk/declarations/2000.htm

UNESCO. (2002). UNESCO: IBE education thesaurus ( $6^{\text {th }}$ ed.). Geneva, UNESCO International Bureau of Education.

Weldon, G. (2010). Post-conflict teacher development: facing the past in South Africa. Journal of Moral Education, 39(3), 353-364.

\section{Copyrights}

Copyright for this article is retained by the author(s), with first publication rights granted to the journal.

This is an open-access article distributed under the terms and conditions of the Creative Commons Attribution license (http://creativecommons.org/licenses/by/4.0/). 